\title{
Road Safety in the Romanian Cities. A Study on Urban Traffic Crashes
}

\author{
Vasile ZOTIC ${ }^{,}$Diana-Elena ALEXANDRU*1, István Oliver EGRESI ${ }^{*}$ \\ *Corresponding author \\ ${ }^{1}$ Babeș-Bolyai University, Faculty of Geography, Centre for Research on Settlements and Urbanism, Cluj-Napoca, ROMANIA \\ $\triangle$ vasile.zotic@ubbcluj.ro (D) https://orcid.org/oooo-0oo2-4489-0637 \\ $\triangle$ diana.alexandru@ubbcluj.ro (D) https://orcid.org/oooo-ooo2-2221-9316 \\ $\triangle$ istvan.egresi@ubbcluj.ro (D) https://orcid.org/oooo-0oo3-0090-5793 \\ DOI: 10.24193/JSSP.2021.2.06 \\ https://doi.org/10.24193/JSSP.2021.2.06
}

K e y w o r d s: road traffic crashes, fatality rate, space-time analysis, road safety, urban areas, Romania

\begin{abstract}
A B S T RA C T
Sustainable urban mobility and road safety have been both a challenge and a priority at the European level for two decades now. Urban road traffic crashes are some of the most difficult issues to tackle by the local administrative planning and development authorities in Europe. The aim of this study was to enhance the focus on urban road safety by providing an illustrative spatial and temporal overview on the road crashes occurred in the cities and towns of Romania and their effects on the people involved. Data related to urban road crashes for a 12-year reference period from 2008 to 2019 were used. Results showed no significant difference in the number of road traffic crashes in 2019 compared to 2008. However, the impact on the people involved show a decrease in severity, the number of road crashes deaths in 2019 being halved compared to 2008. We note a redistribution in the occurrence of these events at the city level, for the period 2008-2019, whilst the most affected are the cities of rank 1 and 2. All rank 1 cities in Romania were detected as hotspots with a high concentration of road traffic crashes and casualties, designated as low-safety road traffic urban poles. We argued in favour of customized and relevant strategies for sustainable and safe urban transport in accordance with the particular features of the cities and towns in Romania, given the varied severity degree of the phenomenon and the specific features of road infrastructure and road traffic.
\end{abstract}

\section{INTRODUCTION}

Sustainable, smart, and safe inter- and intraurban mobility and transport is highly needed in the European Union member states, given that over $70 \%$ of EU citizens live in cities (European Commission, 2021). While mobility within the cities is increasingly difficult and inefficient, about $38 \%$ of Europe's road fatalities still occur in urban areas putting users at risk (European Commission, 2013; European Parliament, 2021). Due to the significant impact of road traffic risks on communities, in the last two decades, the European Commission has initiated a series of five Road Safety Programmes containing detailed measures aimed to improve road safety and reduce the extreme impact of road traffic crashes on the people involved, which should be adopted, adapted and prioritised by the member states in relation to their particular context and needs. The $4^{\text {th }}$ Road Safety Programme (20112020) consisted of seven strategic objectives, with particular emphasis on improving vehicle and infrastructure safety and users' behaviour so that road deaths at the European level would be cut in half by 2020 (European Commission, 2010). The $5^{\text {th }}$ Road Safety Programme (2020-2030) has maintained the objectives of the previous action programme but also proposed several new strategic objectives to encourage the implementation of measures to reduce the gap 
between the various outcomes recorded by the member states, enhance actions towards road safety and reduce the number of seriously injured people in road traffic crashes (European Transport Safety Council, 2018). Therefore, road safety maintains as a priority matter for policy makers and local, national and European authorities.

The abundant specialist literature also proves the interest expressed by researchers in illustrating the manifestation of road crashes from space and time perspectives and evaluating the health, social and economic impact on the people involved and on the society altogether. Road traffic crashes are an important cause of death and disability, especially in developing countries (Dandona and Mishra, 2004), whilst road traffic injuries are the eighth leading cause of death worldwide (Patel et al., 2016). According to the World Health Organization (WHO, 2018), in 2018, more than 15 million people died in traffic crashes and 50 million were injured or permanently disabled worldwide. Road traffic fatalities and injuries are an important socioeconomic burden on hospitals and local communities (Ghandour et al, 2020; Ipingbemi, 2008) and can have important financial and economic costs. Although in the developed countries the number of motor vehicle crashes have been on a descending trend (Lobo et al., 2019), the opposite is true for the developing countries (Abdi et al., 2017; Sumaila, 2013; Patel et al., 2016). There, socio-economic development over the last few decades has brought an increased number of vehicles and more traffic which translated into more traffic accidents (Jones et al., 2020). Similarly, in Romania, better car mobility over the last 30 years, along with the growing number of private cars and increased traffic within and outside urban areas due to urban sprawl and development of metropolitan areas have led to an increased number of car crashes (Benedek et al., 2016, Zotic et al., 2020). Between 2008 and 2015, police records show a number of 133,351 vehicle-to-vehicle crashes, involving 205,127 cars and resulting in 202,396 casualties of which 11,072 deaths - among the highest numbers of the European Union countries (Coşciug et al., 2017). According to Cheng et al. (2019), most of the traffic crashes can be avoided. In order for this to happen, the spatio-temporal pattern of car crashes needs to be carefully analyzed in order to identify the major hotspots along the road network (Benedek et al., 2016), namely road segments with a high concentration of crashes (Anderson, 2007). Hotspots or hot zones are important because they can predict spatial patterns of crashes in the future (Ouni and Belloumi, 2019). Understanding the main reasons for the formation of these hotspots could help with finding solutions in order to mitigate the impacts of road crashes (Ma et al., 2017), design better traffic policies (Benedek et al., 2016), and improve road safety (Steenberghen et al., 2010; Zahran et al., 2017). Also, the identification of the prevalent triggering causes of road traffic crashes, particularly human-related (depending on driver and pedestrian behaviour) is highly decisive for designing measures to increase awareness and improve driving education and eventually enhance road safety (Zotic et al., 2020).

The main aim of this study was to identify the cities and towns that have become hotspots of traffic crashes incidence and emphasize the need for customized road safety measures and urban mobility strategies to mitigate the impact of road traffic crashes on urban communities. The study proves scientific novelty by filling the scientific gap in identifying territorial patterns of road crash incidence in the cities and towns of the country over the past 12 years and their impact on the general urban community, particularly on the persons involved. The results obtained regarding territorial differentiation of road traffic crashes, by illustrating the individualization of urban poles of incidence and impact severity are of practical use, providing both an informational foundation and opportunity to develop customized recommendations for the future urban mobility plans and national urban policy.

\section{THEORY AND METHODOLOGY}

Road traffic crashes are an important research topic in the scientific literature and a great number of studies are published annually on this subject. Traffic crashes may involve one or more vehicles, or vehicles and other participants in traffic (i.e., pedestrians, bicycle drivers). One way to classify traffic crashes is by looking at consequences to human life; thus, we can distinguish two categories of crashes: no injury crashes and crashes with injuries (Ma et al., 2017). Most studies include the analysis of road traffic crashes from either spatial or temporal perspective. Some others used a combined approach to reflect the main characteristics of this phenomenon. Most studies used GIS tools (Zahran et al., 2017; Soltani and Askari, 2017; and Abdulhafedh, 2017, among many others) to map traffic crashes at different spatial levels, such as states or provinces (Erdogan, 2009; Truong et al., 2016); counties (Aguero-Valverde and Jovanis, 2006; Eckley and Curtin, 2013; Liu and Sharma, 2018), or smaller spatial level units, such as census tracts or neighbourhoods (Kingham et al., 2011; Wang and Kockelman, 2013). In highly motorized countries, crashes resulting in injuries are more likely to happen on urban than on rural roads (Elvik et al., 2009), although similar results were obtained in some developing countries, as well. For instance, Galle, Sri Lanka, in which case De Silva et al. (2018) found that urban areas were most prone to road crashes occurrence, especially at intersections (63\%). Urban road intersections were also found to be the main 
hotspot areas. A study on data extended over five years showed that most traffic crashes in Baltimore take place in the central area and the neighbouring districts as well as along the major arterial roads and intersections (Dezman et al., 2016). Also, Chen et al. (2018) investigated the location of car crashes occurred between 2010 and 2012 in a redeveloping area of Shanghai, learning that 21,679 car crash incidents resulted in 24,147 victims, while the most hotspots were located at road intersection than on road segments. Patel et al. (2016) used daily data to map the traffic crashes in Kigali, Rwanda between January 1 and December 31, 2013. The study found that most hotspots were located along the major roads crossing Kigali and in two of the city's busiest downtown areas. Omer et al. (2017) investigated the spatial distribution of vehicle and pedestrian traffic crashes in an urban environment as well as the role played by the volume of vehicle traffic and the number of pedestrians. The study concluded that there are fewer crashes in areas with high pedestrian traffic volume. On the other hand, straight street segments were found to be less safe for pedestrians and safer for vehicles. Using various types of graphs (linear, circular, or radar) authors have attempted to exhaustively illustrate the temporal variation of road traffic crashes during a day, week, month or a year, at different spatial levels (El Sadig et al., 2002; Plug et al., 2011; Rodríguez-Morales et al., 2013). For instance, based on data for the period 20112015, Bellos et al. (2020) argued for the seasonality in the dynamics of road car crashes concluding that, in Greece, the highest frequency of crashes was recorded in the tourist season and in tourist regions, and most often the people involved in these incidents were tourists rather than locals. Their results resonate with the findings of Erdogan et al. (2008) who found that the temporal "hotspots" in the city of Afyonkarahisar in Turkey were the months of August and December, and, more specifically Fridays and the weekends when the analysis is done at the daily scale. Finally, Toran Pour et al. (2016) analyzed the temporal and spatial distribution of pedestrian crashes in Melbourne Metropolitan Area, Australia and, from an hourly perspective found that the most severe accidents generally happened at night, between the hours 7:00 PM and 6:00 AM.

Other studies argued that both the spatial and the temporal effects are important and should be included in the statistical modelling (Liu and Sharma, 2017; 2018). For example, Liu and Sharma (2017) used Bayesian model to research the spatio-temporal characteristics of traffic crashes in Iowa at county level between 2006 and 2015. The study found that fatal crashes displayed a decreasing trend during this time period; however, the rates with which they decreased varied from county to county. The only factor that influenced the number of crashes was vehicle miles travelled (VMT). The authors also argued that the spatial effect played a more important role than the temporal effect. One year later, using the same data set, Liu and Sharma (2018) investigated fatal, major injury and minor injury crashes in the state of Iowa, USA employing a multivariate spatio-temporal Bayesian model. The study concluded that the counties situated in the northern and south-western part of the state tended to have fewer crashes than the other counties. Time-wise, the authors found that the trend for all three types of crashes between 2006 and 2015 was descending. Cheng et al. (2019) used a comprehensive spatio-temporal analysis method (that included spatial autocorrelation and time-space cube analysis) and GIS software to map the road traffic crashes in Wujiang, China. The study identified a number of hotspots, classified them into several types and followed their evolution over time. Bíl et al (2019), using data that extended over a nine-year period (2010-2018), investigated the spatial and temporal situation with the traffic crashes in the rural parts of Czechia's main roads in order to identify the main crash hotspots. The study found that the hotspots made up approximately $7-8 \%$ of the entire road network length but concentrated $50 \%$ of all traffic crashes. Based on the hotspots' evolution over time, the authors distinguished between three types: hotspot emergence (in which the number of crashes followed an ascending trend), stability and disappearance. In the last decade, the amplitude (number and degree of severity), causality, spatial distribution and temporal variation of road traffic crashes have been analysed by several authors, focusing on urban and rural areas in Romania. Covering shorter or longer time spans between 2007 and 2018, most of the studies debated on a wide range of aspects at the national and county level, namely traffic volumes (Cadar et al., 2017), road crashes incidence and dynamics (Târnu and Deac, 2018b), major triggering causes (Târnu and Deac, 2018a; Drosu et al., 2020), material and health impact (Călinoiu et al., 2012; Mincă et al., 2013); at lower spatial scales, we acknowledge the findings on pedestrian safety in large urban agglomerations based on the case of Bucharest, the capital city of Romania (Ivan et al., 2019), on crash incidence, dynamics and patterns, spatial and time distribution in Cluj-Napoca municipality (Ivan and Haidu, 2012; Ivan et al., 2015) and regarding the social aspects of the people involved in car crashes in urban environment (Benedek et al., 2016). However, there have been no comprehensive studies on the urban areas in Romania regarding the incidence of road traffic crashes and their degree of severity, which provided for the opportunity of this study, a prospective analysis which would be useful for local, regional or national authorities and policy makers. In this study, we aimed to reflect the spatial and temporal dynamics of the occurrence of urban road crashes and their effects on 
the people involved over the reference period from 2008 to 2019, illustrating the level of road safety in the cities and towns of Romania, yet, without assessing the economic and social impact given by the values of the indicators calculated. Since the effect of the COVID-19 pandemic on the traffic volume and other related features can hardly be measured, we decided not to include the year 2020 in this analysis. Data were provided by The General Inspectorate of the Romanian Police - Traffic Department (GIRPTD). The novelty of this study lays in the spatial level approach, which is the urban local administrative unit (LAU1). Results are often presented by referring to cities and towns in Romania, categorized by their rank in the national hierarchy (Law 351/2001). The results of the indicators calculated are presented in a time-space frame, mostly comparatively between the start date (2008) and the end date (2019) of the reference period to be able to reveal the variations of their values in terms of location and year. Daily data on the car crashes recorded within the administrative borders of cities and towns were computed and statistically analysed in relation to two aspects: the intensity of urban traffic collisions number of urban road crashes, and the impact of road traffic crashes on the persons involved - number of deceased, severely injured and slightly injured persons. Data were further processed in ArcGIS to represent the spatial distribution of road crashes at the urban LAU level and illustrate the degree of concentration and severity of road crashes among the cities and towns of Romania. The main indicators selected for analysis in this study were calculated for each of the 319 cities and towns in Romania for the entire reference period, as follows: total number of urban road crashes and their effects (number of fatalities, severely injured and slightly injured persons involved in the event); fatality rate (\%) per number of persons involved in urban car crashes; fatality rate per 100,000 urban inhabitants, calculated based on the total number of road traffic fatalities and total urban population, as set by the ISO standard 37120:2018 (ASRO, 2020). To demonstrate the particular characteristics of cities and towns of different ranks regarding road safety we opted to assess their clustering based on the relative deviation from the average values calculated for each of the indicators at the national urban level.

\section{RESULTS AND DISCUSSION}

\subsection{National overview on road traffic crashes incidence}

Urban areas have the highest rate of motorisation which, without doubt, exceeds all efforts for the development of urban transport infrastructure. Much more, in the last decade, large cities have witnessed high dynamics in their spatial development within and outside their administrative borders, new residential areas being developed in periurban areas, while the first steps towards setting up metropolitan areas have been made. All these result in several direct effects: increase in urban agglomeration, increase in traffic intensity, an overlapping of the commuting and transit traffic with the local traffic, creating the most favourable context for the occurrence of road traffic crashes in the urban areas. There is almost an equal value between the road crashes that occur within the built up area of the cities and towns and those occurring outside the urban area, mostly on the classified roads (European, national and county). Road traffic crashes occur mostly in urban areas and this concentration in urban areas is usually caused by the simultaneous transit, metropolitan and local traffic of pedestrians and vehicles within a road network technically not adapted to the current traffic intensity, not capable to efficiently support the continuously increasing traffic. If in the case of cities of rank 3 , we can still note quite reduced values of car crashes, in the case of rank 1 and 2 cities we observe an increase in their number over the reference period. The main objective is to analyse the amplitude of this phenomenon in general and particularly emphasize the impact of road crashes on the persons involved in order to describe the level of road safety in the Romanian cities and if the dynamics of this phenomenon show positive or negative trends during the reference period, with particular focus on the years 2008 and 2019 (Fig. 1).
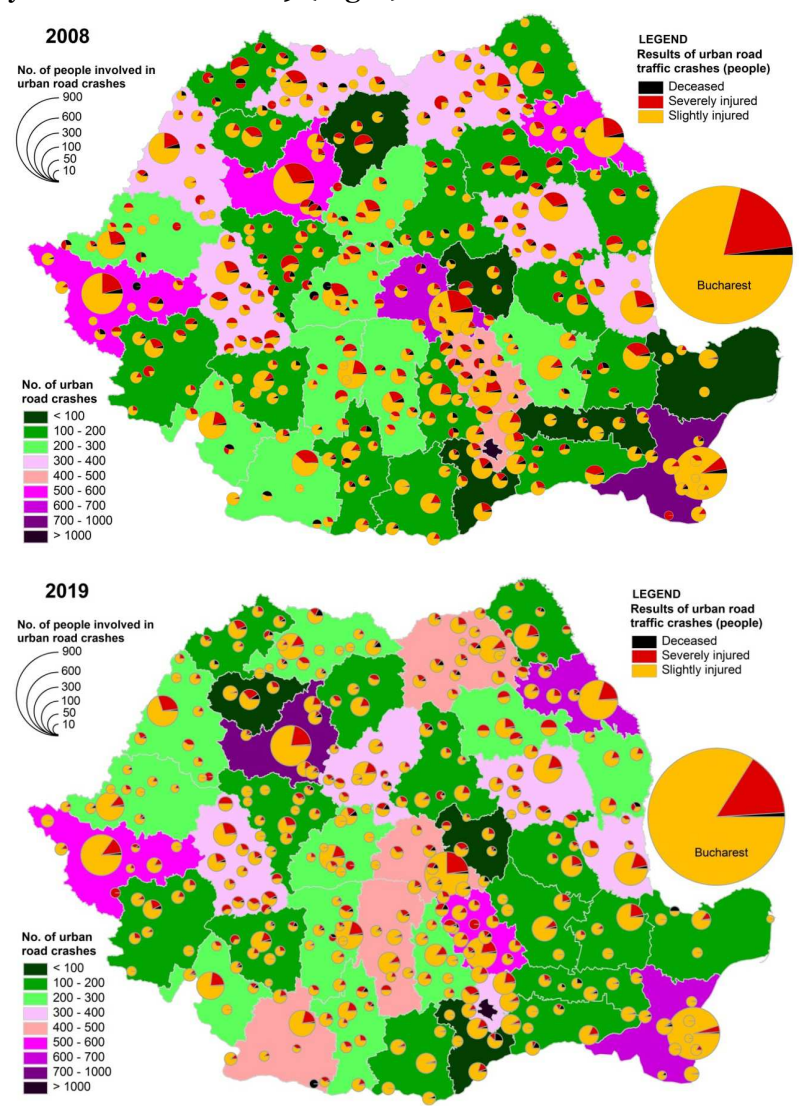

Fig 1. Spatial distribution of urban road traffic crashes and effects on the people involved (2008 and 2019). 
Overall, when looking comparatively at the values in 2008 and 2019, we note a stagnation trend regarding the incidence of car crashes in urban LAUs; in particular, however, we observe an amplification of this phenomenon in all rank 1 cities in the last 5 years of the reference period compared to the descending trend recorded until 2015. It seems that there is a direct relation between the increase in socio-economic development and the increase in the number of road traffic crashes. If we follow the change in the hierarchy of economic urban poles, in the last decade, we can identify the Bucharest-Ilfov area, Cluj-Napoca, Iași and Timişoara, where the number of road crashes shows an increase. Although efforts are made for improving the road infrastructure (smart transport systems, ring roads, highways), this phenomenon is still not reduced, but amplified. Figures 1 visibly display the increase in the incidence of road crashes and their spatial redistribution at county and urban level for the years 2008 and 2019.

High values of the car crashes incidence are maintained on the national roads (DN) in the country, crossing cities of rank 2 and 3 , in which case the intense transit traffic is not supported by other type of roads (ring roads or highways), for instance DN 1 Bucharest Oradea - Borș (border with Hungary) which crosses 25 cities and towns six counties (Ilfov, Prahova, Braşov, Sibiu, Alba, Cluj and Bihor) from south-east to northwest of the country (passing through Otopeni, Ploiești, Câmpina, Comarnic, Sinaia, Bușteni, Azuga, Predeal, Braşov, Ghimbav, Codlea, Făgăraș, Avrig, Sibiu, Miercurea Sibiului, Săliște, Sebeș, Alba Iulia, Teiuş, Aiud, Turda, Cluj-Napoca, Huedin, Aleșd and Oradea); the same applies for other national roads, namely DN 2 Bucharest - Suceava through the cites of Buzău, Focșani, Bacău, Roman; DN 66 Filiași - Simeria crossing several cities and towns along Jiului Valley; DN 69, DN 79 and DN 19 connecting Timişoara - Arad - Oradea - Satu Mare - Sighetu Marmației on the western side of the country; DN 18 and DN 17 connecting the major cities and towns in the northern part of the country from west to east: Baia Mare Sighetu Marmației - Borșa - Câmpulung Moldovenesc - Suceava - Vatra Dornei; DN 6 connecting the capital city with the western part of the country on south-west route through Alexandria, Caracal, Craiova, Drobeta Turnu Severin - Caransebeș - Lugoj - Timişoara; DN 17 connecting the regions of Transylvania and Moldavia from Dej to Suceava through Beclean, Bistrița, Vatra Dornei, Câmpulung Moldovenesc and Gura Humorului; DN 7 connecting Bucharest to Banat region (Nădlac city - border with Hungary) through the Olt valley and crossing Pitești, Râmnicu Vâlcea, Sibiu, Sebeș, Deva and Arad.

Also, there are two atypical situations in Romania, namely the tourist areas around Constanța City (the seaside area) and Prahova Valley (with mountain resorts). In the case of Constanța City, the extreme values of the number of road crashes can be explained by the increase in traffic intensity during the summer season, when the population from all over the country travels towards the seaside resorts and they overlap the traffic from Bucharest (more intense during the weekends) to Constanța. Another reason for the high values of traffic is the limited capacity of the motorway (A2) and the lack of high speed road that would take over the traffic to the farthest southern point of the seaside. This means, that the entire travelling along the seaside from north to south and vice versa is supported only by a national road. In the case of Prahova valley, the main winter tourist destination, with an increase in traffic intensity during the winter season, the increased traffic intensity is caused by people travelling from the south to the north of the country, overlapped by the tourist traffic mainly from south (i.e., Bucharest, Ploiești, Constanța) and from north (i.e., Brașov, Sibiu, Cluj-Napoca); in this case the complete lack of high speed roads determines the overuse of the national road ( $\mathrm{DN}_{1}$ ), usually ending in congestion.

\subsection{Urban road traffic crashes}

The total number of road crashes recorded annually in the urban centres at the national level shows some variation in the period 2008-2019, although with very close values in 2008 and 2019. This is in line with the annual average number of urban road crashes in the Romanian cities. If we looked only at the values at the beginning and at the end of the period, no relevant differences could be observed. However, we note some visible changes in the number of road crashes, a decrease being recorded from 2008 until 2015, followed by a continuous increase until 2019 (Fig. 2).

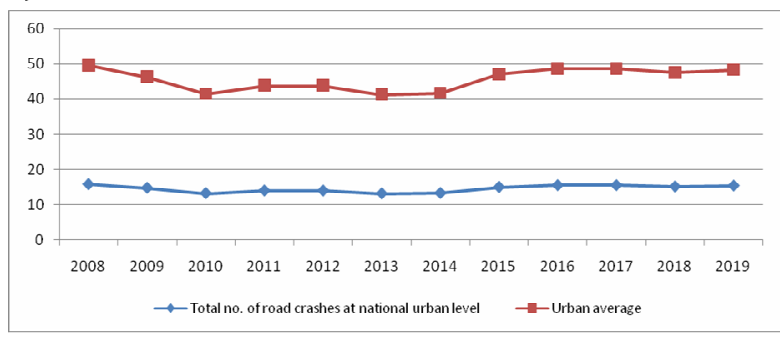

Fig. 2. Comparative trends in the absolute and average values of urban road crashes at the national level for the period 2008-2019.

To confirm the relevance of the general feature regarding the intensity of the phenomenon based on the average number of road crashes at the city level, we calculated the absolute and relative deviation for the entire group of 319 cities and towns and we observed how much the individual values vary from the mean, and ultimately conclude which and how many of the urban LAUs are clustered in a specific interval. We 
performed data classification and class breaks were created with unequal value ranges; we opted for four equal intervals for the negative values of relative deviation (o-25\%, 25-50\%, 50-75\% and 75-100\%), and seven unequal intervals for the positive values of relative deviation (0-200\%, 200-400\%, 400-600\%, 600-800\%, 800-1000\%, 1000-5000\% and >5000\%) due to several cases of extremely high values in the series. Results on the number of cities and towns by classes were presented Table 1 . It can clearly be observed that for all years in the reference period, about $50 \%$ of the urban LAUs in Romania are part of the group of cities and towns with the least intense manifestation of the phenomenon, along with another $35 \%$ of them recording values below the national urban average. The rest of $15 \%$ represent cities that record values highly above the average, and which critically influence the mean value at the urban national level, every year. If in the case of towns with no road crashes, it is not so relevant to mention examples, in the case of the cities with extremely high values, we need to observe if the highest values are maintained for the same cities at the national level, for the entire period under analysis, and comparatively between the start year and end year of the reference period.

Table 1. Number of cities and towns distributed within classes of relative deviation from the mean value of urban road traffic crashes in the reference period 2008-2019.

\begin{tabular}{|l|rrrrrrrrrrrrr}
$\begin{array}{c}\text { Relative deviation } \\
(\%)\end{array}$ & $\mathbf{2 0 0 8}$ & $\mathbf{2 0 0 9}$ & $\mathbf{2 0 1 0}$ & $\mathbf{2 0 1 1}$ & $\mathbf{2 0 1 2}$ & $\mathbf{2 0 1 3}$ & $\mathbf{2 0 1 4}$ & $\mathbf{2 0 1 5}$ & $\mathbf{2 0 1 6}$ & $\mathbf{2 0 1 7}$ & $\mathbf{2 0 1 8}$ & $\mathbf{2 0 1 9}$ \\
\hline$(-100)-(-75)$ & 169 & 166 & 170 & 158 & 168 & 176 & 172 & 157 & 166 & 162 & 151 & 159 \\
$(-75)-(-50)$ & 69 & 73 & 61 & 73 & 66 & 56 & 60 & 72 & 62 & 67 & 81 & 68 \\
$(-50)-(-25)$ & 24 & 22 & 24 & 31 & 27 & 30 & 32 & 29 & 30 & 24 & 20 & 27 \\
$(-25)-0$ & 13 & 11 & 21 & 10 & 11 & 15 & 9 & 18 & 15 & 16 & 16 & 17 \\
$0-200$ & 23 & 29 & 24 & 28 & 28 & 22 & 26 & 22 & 24 & 30 & 32 & 29 \\
$200-400$ & 13 & 9 & 7 & 5 & 6 & 7 & 8 & 10 & 9 & 7 & 8 & 7 \\
$400-600$ & 2 & 3 & 6 & 8 & 6 & 6 & 4 & 3 & 5 & 4 & 3 & 5 \\
$600-800$ & 2 & 1 & 3 & 2 & 3 & 2 & 3 & 3 & 3 & 4 & 4 & 2 \\
$800-1000$ & 2 & 3 & 1 & 2 & 1 & 2 & 1 & 2 & 1 & 1 & 1 & 2 \\
$1000-5000$ & 1 & 1 & 1 & 1 & 2 & 2 & 3 & 2 & 3 & 3 & 2 & 2 \\
$>5000$ & 1 & 1 & 1 & 1 & 1 & 1 & 1 & 1 & 1 & 1 & 1 & 1 \\
Total no. of cities & 319 & 319 & 319 & 319 & 319 & 319 & 319 & 319 & 319 & 319 & 319 & 319 \\
\hline
\end{tabular}

In $2008,86.20 \%$ of the urban centres of rank 2 and 3 recorded negative absolute values when compared to the average national urban number of road

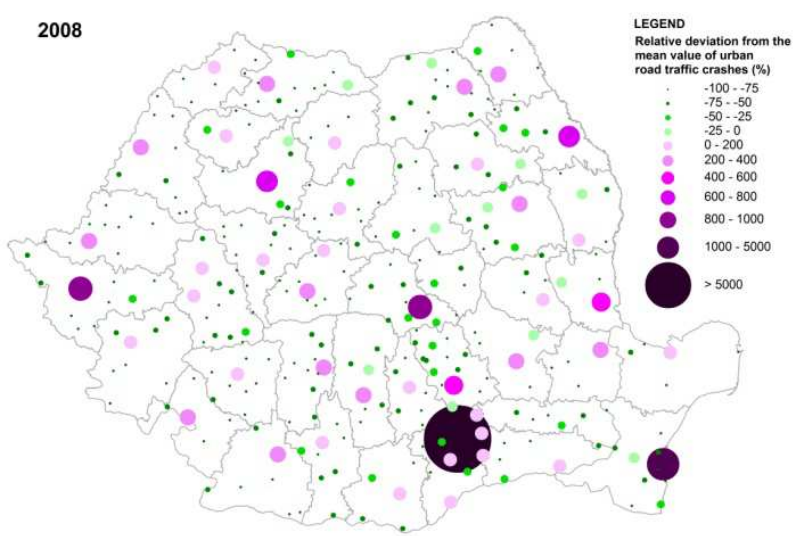

crashes (Fig. 3). However, there are 32 cities and towns of rank 2 and 3, where the number of recorded road crashes was higher than average.

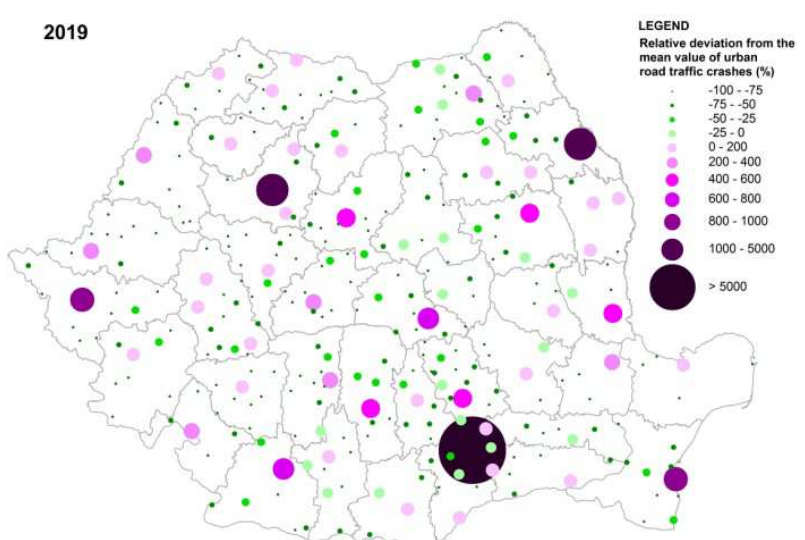

Fig. 3. Classification of cities based on relative deviation from the mean value of car crashes, in 2008 and 2019.

In this category we find the towns included in the metropolitan area of the capital city (Bragadiru, Pantelimon, Popeşti Leordeni and Voluntari) and 3 others (Hunedoara, Bârlad and Mediaş) had values slightly over the average); on the other hand, some 25 cities (of rank 2 and 3) representing county seats and spatially distributed within the entire territory of the country recorded a number of crashes up to double the average value (Alba Iulia, Bistrița, Buzău, Reșița, Târgoviște, Târgu Jiu, Deva, Călărași, Târgu Mureș, 136
Piatra-Neamț, Giurgiu, Slatina, Satu Mare, Zalău, Alexandria, Tulcea, and Focşani) or even 3-4 times the average value (Arad, Piteşti, Botoşani, Baia Mare, Drobeta Turnu Severin, Sibiu, Suceava, Râmnicu Vâlcea); some of them had values very close to the extreme maximum values recoded by the rank 1 cities. All of the rank 1 cities in the country registered the highest values of absolute deviation compared to the average, for instance from 4-6 times higher than average (Bacău, Oradea, Craiova, Brăila, Ploiești, 
Galați) and up to 10 times higher than average (Iași, Cluj-Napoca, Brașov, Timișoara), along with Constanța, which recorded a value more than 15 times the average. Bucharest recorded 100 times more road crashes than the national urban average and it is an extreme case.

In 2019, there are no major differences in the structural distribution of shares characterizing the deviation values from the average number of road crashes recorded in the cities and towns of Romania. More than $80 \%$ of the cities and towns recorded values below the national urban average, whilst about $15 \%$ of them still held the highest values above the average. To observe if there was any change in the distribution of road crashes by urban LAUs, we performed a detailed analysis, and we concluded the following facts: the highest number of road crashes remains constant and it is registered in the 11 rank 1 cities in the country; there is a visible decrease in the value recorded in Constanța (in 2019, down to ten times the national urban average); two other poles of incidence appeared (the cities of Cluj-Napoca and Iași) with a number of road crashes above ten times the national average, followed by Timișoara, Braşov and Craiova.

The relative growth in the car crashes values calculated for the entire reference period 2008-2019 reflects relevant positive and negative dynamics regarding the car crashes incidence in the cities and towns of Romania (Fig. 4).

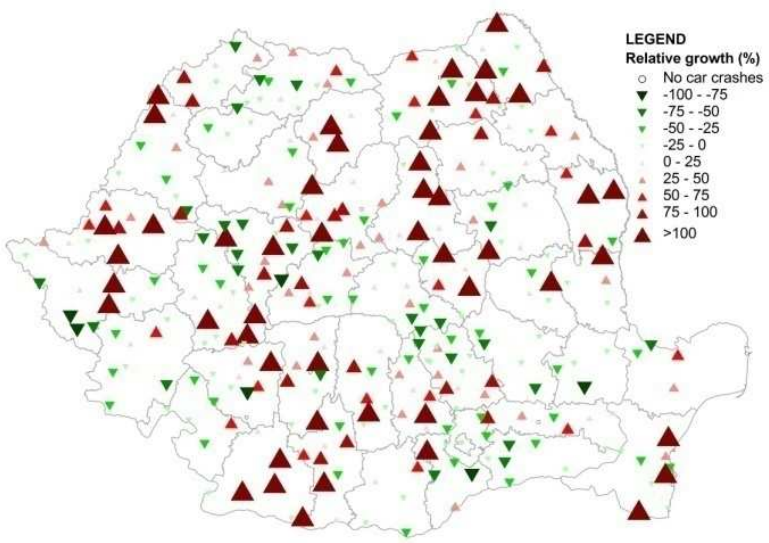

Fig. 4. Classification of cities based on relative growth in the number of urban road traffic crashes, for the period 2008-2019.

Compared to 2008, in 2019, almost $60 \%$ of the cities and towns in Romania recorded an absolute increase in the number of road crashes occurred within their administrative borders. More specifically, almost all rank 1 and rank 2 cities representing county seats show an increased intensity of the phenomenon of the road crashes, which means they are affected by traffic intensification and congestion. All rank 1 cities stand out as poles of risks in urban traffic showing low levels of security and safety regarding road transportation, although some of them showed trends of slight decrease in the value of this indicator (Oradea, Brăila, Braşov, Constanța, Galați). Therefore, these increased values of road crashes, along with intense traffic and the low level of road security should be considered in designing the new urban mobility plans, and when attempting to redesign, rehabilitate and develop road infrastructure. Also, specific strategies for urban green mobility and enhanced public transportation use should be individually customized for each city.

\subsection{Effects of road crashes}

Road crashes occur due to a wide range of reasons. Broadly, their impact is three-fold: first, they may involve one or more vehicles and a certain number of persons; second, depending on their severity, they affect the persons involved resulting in slight or severe injuries, or even deaths; third, they have a negative impact on the vehicles involved and on the road infrastructure, resulting in material damages of a certain level of costs. In this study, we aimed to reveal the effects of road crashes on the people involved, focusing on the road safety in urban areas, yet, without assessing the economic and social impact given by the values of the indicators calculated.

Between 2008 and 2019, about 18,00o people have been involved annually in car crashes in the Romanian cities and towns, and this value has slightly changed during this reference period and especially when comparing the years 2008 and 2019. The trend has been almost identical with that of the number of car crashes for the reference period. However, there were three years in which the number of people involved in traffic crashes actually decreased, particularly in 2010, 2013 and 2018. The peak value of almost 20,000 people was recorded in 2008, and the lowest in 2013 (when the number of people involved was about $20 \%$ lower than in 2008). After 2013, a continuous increase was maintained, with a small drop in 2018. The average number of persons involved in car crashes calculated for the urban areas at national level is of about 60 people/city every year. We must note, however, that every year in the reference period, the number of involved people in car crashes in Bucharest, the capital city of Romania, accounts for about $30 \%$ of the total number of people involved in car crashes at the urban national level. To highlight the discrepancies between the levels of intensity of this indicator for the cities and towns of various ranks, we calculated the absolute and relative deviation from the mean value and we learned the following: notable differences in the values of this indicator are observed between the cities and towns of different ranks; while the capital city accounts for 30\% of the total number of persons involved in car crashes within the urban administrative borders, municipalities representing the county seats in Romania account for another about 50\%; about $85 \%$ of the cities and towns in Romania record number of persons involved in car crashes below the urban average in 2019 and in 2008; 
this means that most of the car crashes occur in the cities of rank 1 and 2, which are affected by the intensification of traffic, increase in the number of vehicles and conjunction of three vectors: local traffic, transit traffic and commuting.

The most affected cities by this negative feature and recording the highest number of people affected by road crashes are: in 2008 - Constanța (the peak value), Brașov, Timișoara, Cluj-Napoca, and Iași with values about ten times higher than the urban average, Galați, Ploiești, Oradea and Râmnicu Vâlcea with values about 5 to 8 times the urban average; in 2009 - Iași, Cluj-Napoca, Constanța and Timișoara hold the highest values above the urban average (8 to 11 times), closely followed by Craiova, Brașov, Ploiești, Galați, Pitești, Bacău and Târgu Mureș (with values 5 to 8 times higher than the urban average) (Table 2).

Table 2. Number of people involved in road traffic crashes in rank 1 cities and Bucharest, over the reference period 20082019

\begin{tabular}{|l|rrrrrrrrrrrrr} 
Rank 1 city & $\mathbf{2 0 0 8}$ & $\mathbf{2 0 0 9}$ & $\mathbf{2 0 1 0}$ & $\mathbf{2 0 1 1}$ & $\mathbf{2 0 1 2}$ & $\mathbf{2 0 1 3}$ & $\mathbf{2 0 1 4}$ & $\mathbf{2 0 1 5}$ & $\mathbf{2 0 1 6}$ & $\mathbf{2 0 1 7}$ & $\mathbf{2 0 1 8}$ & $\mathbf{2 0 1 9}$ \\
\hline Bacău & 249 & 289 & 286 & 295 & 275 & 267 & 311 & 304 & 327 & 333 & 278 & 325 \\
Oradea & 299 & 285 & 288 & 314 & 308 & 247 & 235 & 206 & 217 & 230 & 187 & 192 \\
Brăila & 217 & 175 & 180 & 177 & 127 & 126 & 133 & 171 & 233 & 210 & 207 & 187 \\
Brașov & 651 & 560 & 438 & 456 & 491 & 397 & 513 & 511 & 480 & 516 & 483 & 430 \\
Cluj-Napoca & 542 & 575 & 465 & 513 & 604 & 547 & 597 & 584 & 738 & 731 & 605 & 675 \\
Constanța & 933 & 835 & 856 & 896 & 816 & 753 & 851 & 816 & 778 & 703 & 606 & 583 \\
Craiova & 204 & 197 & 191 & 365 & 441 & 479 & 434 & 439 & 464 & 538 & 465 & 474 \\
Galați & 357 & 322 & 271 & 290 & 372 & 344 & 340 & 411 & 440 & 451 & 357 & 358 \\
Iași & 511 & 538 & 473 & 568 & 499 & 502 & 543 & 694 & 738 & 731 & 700 & 727 \\
Ploiești & 309 & 386 & 337 & 402 & 360 & 379 & 363 & 415 & 381 & 469 & 404 & 379 \\
Timișoara & 555 & 459 & 415 & 362 & 405 & 310 & 392 & 592 & 615 & 533 & 518 & 535 \\
Bucharest & 5969 & 5224 & 4468 & 4502 & 4389 & 4167 & 3746 & 4242 & 4126 & 3979 & 4216 & 4484 \\
\hline
\end{tabular}

Trends over the reference period are consistent with those observed in the case of the number of crashes. While the overall number of persons involved in road crashes has only but slightly changed in 2019 compared to 2008, we note a different distribution of shares between the cities of Romania. In 2019, more of the municipalities of rank 1 and 2 were negatively affected by road crashes in terms of people involved (Fig. 5).

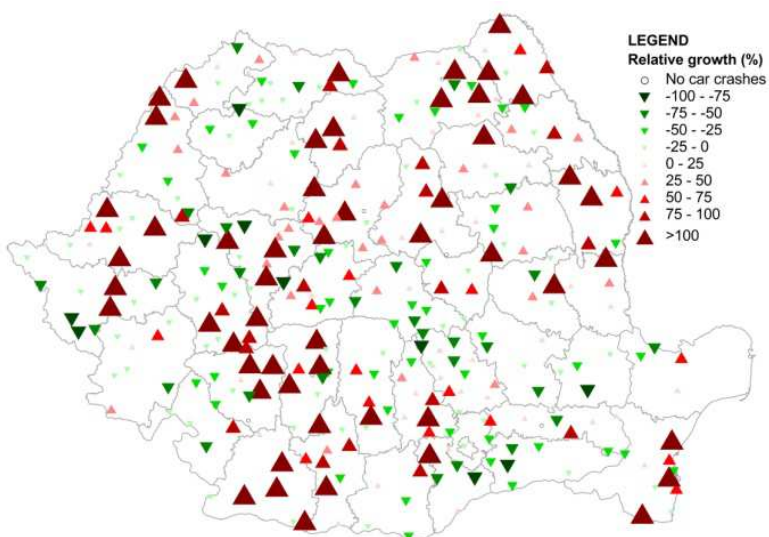

Fig. 5. Classification of cities based on relative growth in the number of persons involved in road traffic crashes, for the period 2008-2019.

The relative growth for the entire reference period 2008-2019 reveals both positive and negative changes regarding the number of people involved in road crashes in the cities and towns in Romania. Compared to 2008, in 2019, almost half of the cities and towns showed a relative decrease in the number of persons involved in road traffic crashes. However, we 138 also note that about $16 \%$ of the cities and towns in Romania recorded great relative increase in the number of persons involved of more than $100 \%$, up to $800 \%$, the highest values being recorded mostly by rank 3 cities (i.e., Recaş and Techirghiol - 800\%, Salcea 575\%, Sebiș and Băilești - 500\%, Segarcea, Berești, Bălan, Buziaş, Darabani - 400\%), and some rank 2 and 1 cities (Caracal - 264\%, Carei - 145\%, Craiova - 132\%, Sebeș and Drăgășani - 127\%, Târgu Mureș and Vaslui 107\%, Târnăveni - 120\%).

The severity of the road crashes can be measured by the effects on the people involved. They are classified into three categories: deceased, severely injured and slightly injured.

Almost 6,000 people were killed in severe urban car crashes in the entire reference period. If in 2008, the total number of fatalities resulted from severe car crashes in urban areas in Romania accounted for $4.19 \%$ of the total number of persons involved, which is also the highest value registered in the entire reference period, further towards 2019, this share almost halved, down to $2.35 \%$, which proves a notable positive change in the effects of urban car crashes. The highest number of fatalities was also recorded by Bucharest, every year, placing it at a great distance from any other city in Romania. Still, compared to 2008, when the highest value of 144 persons killed in car crashes was recorded, we note a remarkable decrease in 2019, down to 55 .

The relative growth for the entire reference period 2008-2019 reveals both positive and negative changes regarding the number of fatalities caused by road crashes in the cities and towns in Romania. 
Compared to 2008, in 2019, almost half of the cities and towns showed a negative relative growth in the number of persons killed in road traffic crashes (Table 3, Fig. 6). However, we also note that almost $18 \%$ of the cities and towns in Romania recorded positive relative growth in the number of fatalities (up to 400\%), the highest values being recorded mostly by rank 2 cities (i.e., Onești - 400\%; Oltenița, Slobozia, and Câmpulung Moldovenesc - 300\%; Codlea, Sfântu Gheorghe, Novaci and Gura Humorului - 200\%), and Craiova (200\%).

Table 3. Number of cities recording negative and positive relative growth in the number of road traffic deaths, yearly, for the entire period.

\begin{tabular}{|c|c|c|c|c|c|c|c|c|c|c|c|c|}
\hline \multirow{2}{*}{$\begin{array}{c}\text { Relative growth } \\
(\%)\end{array}$} & $\begin{array}{l}2008- \\
2009\end{array}$ & $\begin{array}{l}2009- \\
2010\end{array}$ & $\begin{array}{l}2010- \\
2011\end{array}$ & $\begin{array}{l}2011- \\
2012\end{array}$ & $\begin{array}{l}2012- \\
2013\end{array}$ & $\begin{array}{l}2013- \\
2014\end{array}$ & $\begin{array}{l}2014- \\
2015\end{array}$ & $\begin{array}{l}2015- \\
2016\end{array}$ & $\begin{array}{l}2016- \\
2017\end{array}$ & $\begin{array}{l}2017- \\
2018\end{array}$ & $\begin{array}{l}\text { 2018- } \\
2019\end{array}$ & $\begin{array}{l}2008- \\
2019\end{array}$ \\
\hline & \multicolumn{12}{|c|}{ Number of cities and towns } \\
\hline$(-100)-(-75)$ & 80 & 63 & 53 & 64 & 57 & 58 & 59 & 68 & 52 & 64 & 49 & 88 \\
\hline$(-75)-(-50)$ & 20 & 12 & 14 & 8 & 6 & 14 & 9 & 6 & 8 & 4 & 7 & 24 \\
\hline$(-50)-(-25)$ & 22 & 30 & 15 & 24 & 18 & 14 & 13 & 17 & 20 & 16 & 18 & 32 \\
\hline$(-25)-0$ & 9 & 6 & 9 & 8 & 6 & 6 & 5 & 5 & 4 & 4 & 10 & 3 \\
\hline $0-25$ & 35 & 27 & 37 & 25 & 28 & 25 & 33 & 28 & 32 & 37 & 34 & 30 \\
\hline $25-50$ & 14 & 7 & 8 & 7 & 4 & 7 & 3 & 5 & 5 & 7 & 4 & 5 \\
\hline $50-75$ & 0 & 1 & 1 & 0 & 0 & 1 & 3 & 2 & 2 & 0 & 1 & 2 \\
\hline $75-100$ & 13 & 10 & 15 & 8 & 8 & 14 & 12 & 7 & 7 & 12 & 11 & 8 \\
\hline$>100$ & 11 & 13 & 9 & 9 & 15 & 7 & 8 & 11 & 7 & 11 & 14 & 12 \\
\hline No deaths & 115 & 150 & 158 & 166 & 177 & 173 & 174 & 170 & 182 & 164 & 171 & 115 \\
\hline Total no. of cities & 319 & 319 & 319 & 319 & 319 & 319 & 319 & 319 & 319 & 319 & 319 & 319 \\
\hline
\end{tabular}

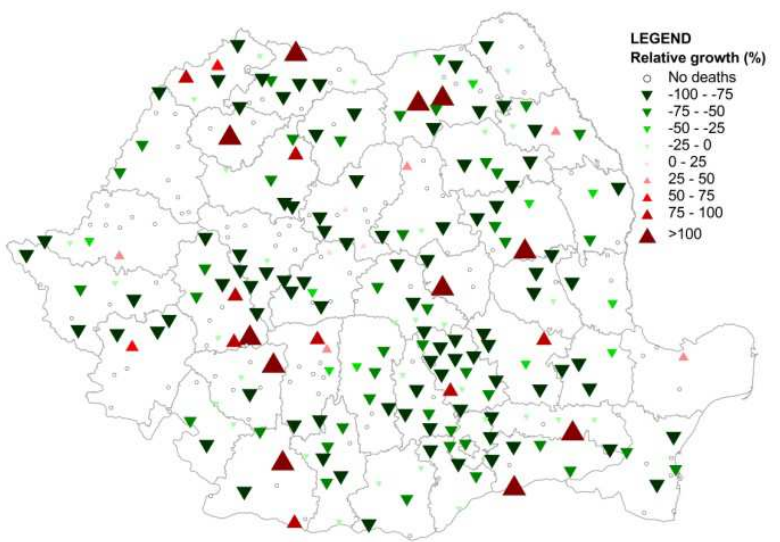

Fig. 6. Classification of cities based on relative growth in the number of deceased people, for the period 20082019.

The second indicator reflecting the severity of road crashes is the number of severely injured persons. In this case, the value recorded in 2019 represents $16.96 \%$ of the total number of persons involved. Compared to the value recorded in 2008 (accounting for $21.86 \%$ ), this also shows decrease, although not so clear as in the case of fatalities. However, the temporal variation between the start year (2008) and the end year (2019) of the reference period shows a positive fact, in that in almost $70 \%$ of the cities and towns, of which 28 municipalities representing county seats, we found a negative relative growth (Table 4).

We also note that about $12 \%$ of the cities and towns in Romania recorded great positive relative increase in the number of persons severely injured, from $100 \%$ up to $800 \%$; the highest values being recorded mostly by rank 2 and 3 cities (i.e., Petrila and Tulcea - 800\%, Caracal - 700\%, Iernut and Mărăşeşti - 400\%, Balș - 350\%, Beiuş, Podu Iloaiei, and Strehaia - 300\%) (Fig. 7).

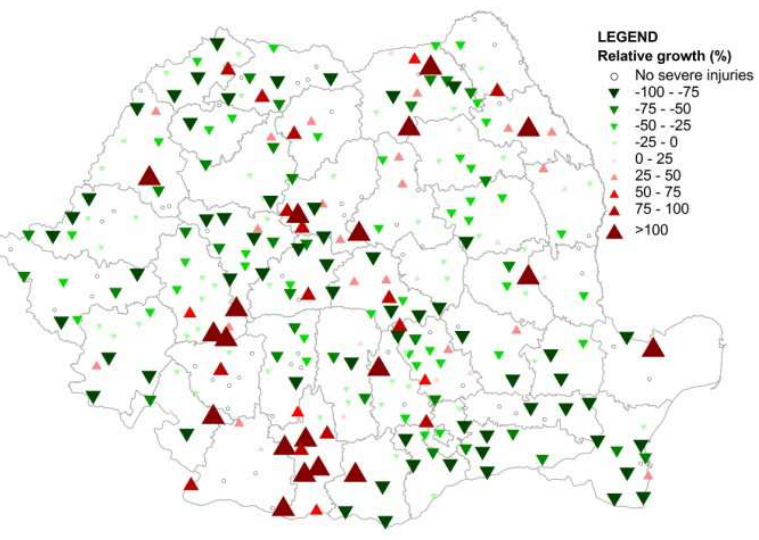

Fig. 7. Classification of cities based on relative growth in the number of severely injured people, for the period 2008-2019.

On the other hand, in the case of slightly injured persons, which are the most numerous, shares vary between $70 \%$ and $80 \%$ per year during the entire period. The value recorded in 2019 (14,950 people) exceeded a little the one in 2008 (14,303 people); yet, relative to the total number of persons involved, we detect an overall increase of about $8 \%$.

The relative growth for the entire reference period 2008-2019 reveals both positive and negative changes regarding the number of slightly injured people in road crashes in the cities and towns in Romania. Compared to 2008, in 2019, about $36 \%$ of the cities and towns showed a negative relative growth (Table 5, Fig. 8 ). However, we also note that about $12 \%$ of the cities and towns in Romania recorded extraordinary positive relative growth in the number of slightly injured people (up to $1250 \%$ ), the highest values being recorded mostly by rank 2 and 3 cities (i.e., Sebeş and Lipova - 1250\%; Carei, Techirghiol, Băilești and Salcea - 800\%; Teiuș, Slănic-Moldova and Năvodari - 400\%; Chișineu-Cris, 
Valea lui Mihai, Năsăud, Darabani, Anina, Răcari,

Mărășești and Odobești - 300-400\%).

Bălan, Hațeg, Piatra-Olt, Buziaș, Băile Olănești, Brezoi,

Table 4. Number of cities recording negative and positive relative growth in the number of severely injured people, yearly, for the entire period.

\begin{tabular}{|c|c|c|c|c|c|c|c|c|c|c|c|c|}
\hline \multirow{2}{*}{$\begin{array}{c}\text { Relative growth } \\
(\%)\end{array}$} & $\begin{array}{l}2008- \\
2009\end{array}$ & $\begin{array}{l}2009- \\
2010\end{array}$ & $\begin{array}{l}2010- \\
2011\end{array}$ & $\begin{array}{l}2011- \\
2012\end{array}$ & $\begin{array}{l}2012- \\
2013\end{array}$ & $\begin{array}{l}2013- \\
2014\end{array}$ & $\begin{array}{l}2014- \\
2015\end{array}$ & $\begin{array}{l}2015- \\
2016\end{array}$ & $\begin{array}{l}2016- \\
2017\end{array}$ & $\begin{array}{l}2017- \\
2018\end{array}$ & $\begin{array}{l}2018- \\
2019\end{array}$ & $\begin{array}{l}2008- \\
2019\end{array}$ \\
\hline & \multicolumn{12}{|c|}{ Number of cities and towns } \\
\hline$(-100)-(-75)$ & 30 & 41 & 29 & 32 & 37 & 28 & 33 & 38 & 40 & 33 & 45 & 57 \\
\hline$(-75)-(-50)$ & 20 & 19 & 21 & 21 & 18 & 25 & 25 & 21 & 24 & 10 & 21 & 26 \\
\hline$(-50)-(-25)$ & 46 & 51 & 33 & 38 & 48 & 44 & 35 & 64 & 44 & 47 & 34 & 50 \\
\hline$(-25)-0$ & 40 & 33 & 34 & 31 & 41 & 25 & 22 & 31 & 29 & 30 & 37 & 22 \\
\hline $0-25$ & 58 & 60 & 63 & 70 & 54 & 60 & 68 & 47 & 60 & 61 & 69 & 43 \\
\hline $25-50$ & 20 & 18 & 28 & 27 & 25 & 23 & 24 & 16 & 23 & 20 & 15 & 20 \\
\hline $50-75$ & 3 & 8 & 8 & 8 & 10 & 9 & 11 & 4 & 7 & 14 & 11 & 6 \\
\hline $75-100$ & 19 & 17 & 11 & 21 & 21 & 17 & 21 & 15 & 19 & 24 & 11 & 14 \\
\hline$>100$ & 21 & 21 & 34 & 24 & 16 & 33 & 35 & 33 & 20 & 23 & 25 & 19 \\
\hline No severe injuries & 62 & 51 & 58 & 47 & 49 & 55 & 45 & 50 & 53 & 57 & 51 & 62 \\
\hline Total no. of cities & 319 & 319 & 319 & 319 & 319 & 319 & 319 & 319 & 319 & 319 & 319 & 319 \\
\hline
\end{tabular}

Table 5. Number of cities recording negative and positive relative growth in the number of slightly injured people in car crashes, yearly, for the entire period.

\begin{tabular}{|c|c|c|c|c|c|c|c|c|c|c|c|c|}
\hline \multirow{2}{*}{$\begin{array}{c}\text { Relative growth } \\
(\%)\end{array}$} & \multirow[t]{2}{*}{$\begin{array}{l}2008- \\
2009\end{array}$} & \multirow[t]{2}{*}{$\begin{array}{l}2009- \\
2010\end{array}$} & \multirow[t]{2}{*}{$\begin{array}{l}2010- \\
2011\end{array}$} & \multirow[t]{2}{*}{$\begin{array}{l}2011- \\
2012\end{array}$} & $\begin{array}{c}2012- \\
2013\end{array}$ & $\begin{array}{l}2013- \\
2014\end{array}$ & $\begin{array}{l}2014- \\
2015\end{array}$ & $\begin{array}{c}2015- \\
2016\end{array}$ & $\begin{array}{c}2016- \\
2017\end{array}$ & $\begin{array}{c}2017- \\
2018\end{array}$ & $\begin{array}{c}2018- \\
2019\end{array}$ & $\begin{array}{l}2008- \\
2019\end{array}$ \\
\hline & & & & & \multicolumn{8}{|c|}{ Number of cities and towns } \\
\hline$(-100)-(-75)$ & 13 & 30 & 17 & 19 & 21 & 14 & 17 & 7 & 15 & 14 & 15 & 11 \\
\hline$(-75)-(-50)$ & 29 & 30 & 20 & 26 & 33 & 22 & 14 & 15 & 16 & 22 & 20 & 25 \\
\hline$(-50)-(-25)$ & 57 & 70 & 33 & 45 & 49 & 38 & 40 & 49 & 47 & 63 & 37 & 42 \\
\hline$(-25)-0$ & 47 & 52 & 49 & 47 & 62 & 54 & 37 & 47 & 62 & 64 & 54 & 38 \\
\hline $0-25$ & 57 & 54 & 66 & 76 & 50 & 66 & 80 & 74 & 77 & 80 & 84 & 47 \\
\hline $25-50$ & 32 & 27 & 37 & 34 & 28 & 31 & 32 & 38 & 26 & 22 & 34 & 39 \\
\hline $50-75$ & 18 & 11 & 15 & 12 & 10 & 23 & 17 & 15 & 19 & 10 & 18 & 17 \\
\hline $75-100$ & 20 & 17 & 28 & 16 & 11 & 21 & 23 & 19 & 19 & 9 & 17 & 11 \\
\hline$>100$ & 31 & 21 & 31 & 29 & 32 & 30 & 45 & 40 & 29 & 21 & 33 & 74 \\
\hline No slight injuries & 15 & 7 & 23 & 15 & 23 & 20 & 14 & 15 & 9 & 14 & 7 & 15 \\
\hline Total no. of cities & 319 & 319 & 319 & 319 & 319 & 319 & 319 & 319 & 319 & 319 & 319 & 319 \\
\hline
\end{tabular}

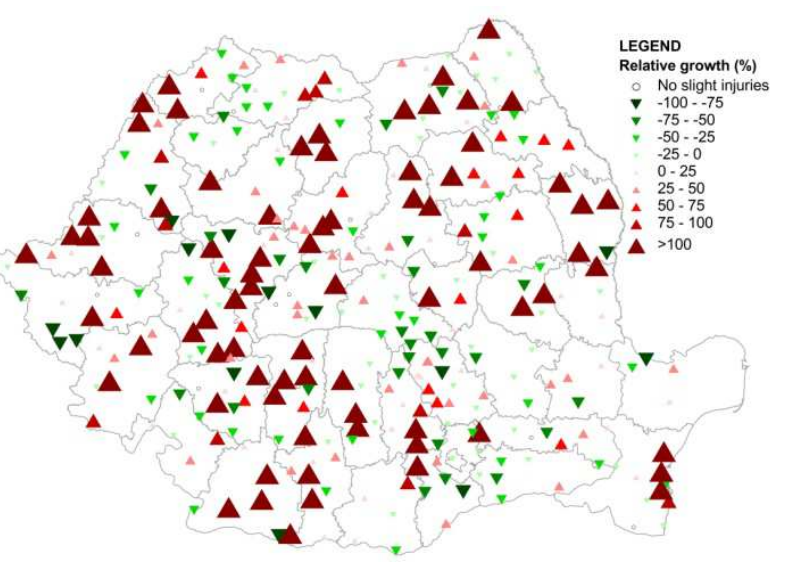

Fig. 8. Classification of cities based on relative growth in the number of slightly injured people, for the period 2008-2019.
The rate of road traffic crashes and, particularly, fatality rate can serve as relevant indicators to be considered when planning for sustainable and smart urban mobility, namely for higher safety of the transport system, better management of the congested and complex urban road network, enhanced enforcement of road safety regulations, improved road conditions and better management of private and public transport. As defined by the standard indicator ISO 37101 - Smart cities, sustainable communities, road traffic deaths are the most severe issues that need to be considered and managed relative to traffic safety, which is in connection with urban mobility, healthy and safe urban communities, and better services and infrastructures (ASRO, 2020). 
Fatality rate was calculated as the number of deaths caused by road traffic crashes per 100,000 urban inhabitants in 2008 and 2019 (Fig. 9).
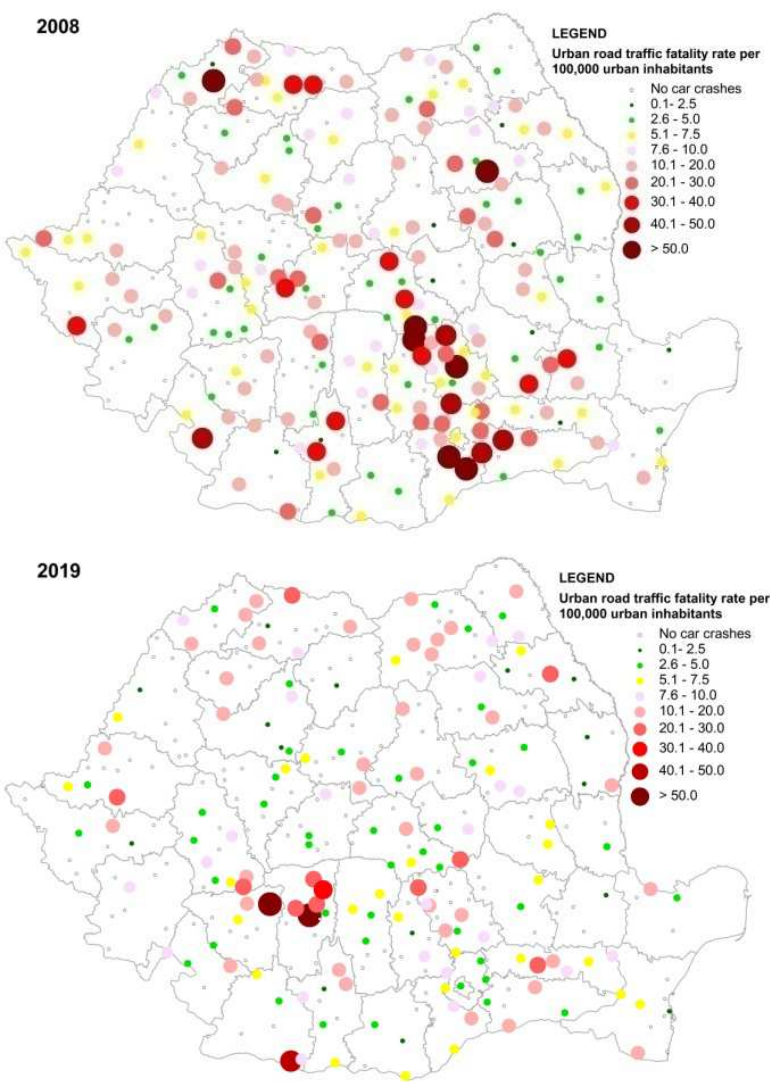

Fig. 9. Spatial distribution of cities per classes of fatality rate in 2008 and 2019.

About 25\% of the Romanian towns did not record any deaths caused by car crashes in both years under analysis and other $25 \%$ cities and towns of rank 2 and 3 recorded an increase in the value of this indicator in 2019 compared to 2008. Different maximum values of road traffic deaths were registered in 2008 (144) and in 2019 (110), which show a general decrease in the number of fatalities per 100,000 urban inhabitants in the Romanian cities and towns. Overall, all rank 1 cities showed a decrease in the value of fatality rate, except for Craiova; the same positive tendency is applicable for rank 2 municipalities, except for ten of them, which showed increased values in 2019 when compared to 2008 (Reșița, Sfântu Gheorghe, Giurgiu, Târgu Jiu, Slobozia, Târgu Mureș, Zalău, Satu Mare, Tulcea and Focșani). Either way, these are quite high values when compared to the ones recorded at the European level or compared to other European member states. The average fatality rate at the European level was 42 in 2018, while Romania was ranked first for this negative indicator, with 85 fatalities per million inhabitants, compared to Sweden with a value of 18 (European Parliament, 2021). The highest values of the fatality rate are mostly recorded by towns, since the lower the total number of urban inhabitants, the higher the fatality rate. Alternatively, we calculated the road traffic death rate as a share of deceased people from the total number of the persons involved in road traffic crashes in 2008 and 2019. Results showed that almost $25 \%$ of the towns did not record any deaths caused by car crashes in both years under analysis. Some $80 \%$ of the cities and towns in Romania show a tendency of decrease in the death rate in 2019 as compared to 2008. All rank 1 cities show a decrease in the value of death rate, except for Craiova and 6 other municipalities (Reșița, Sfântu Gheorghe, Slobozia, Zalău, Satu Mare, and Focșani). Data on the other rank 2 municipalities reveal a positive tendency of rate reduction (Fig. 10).

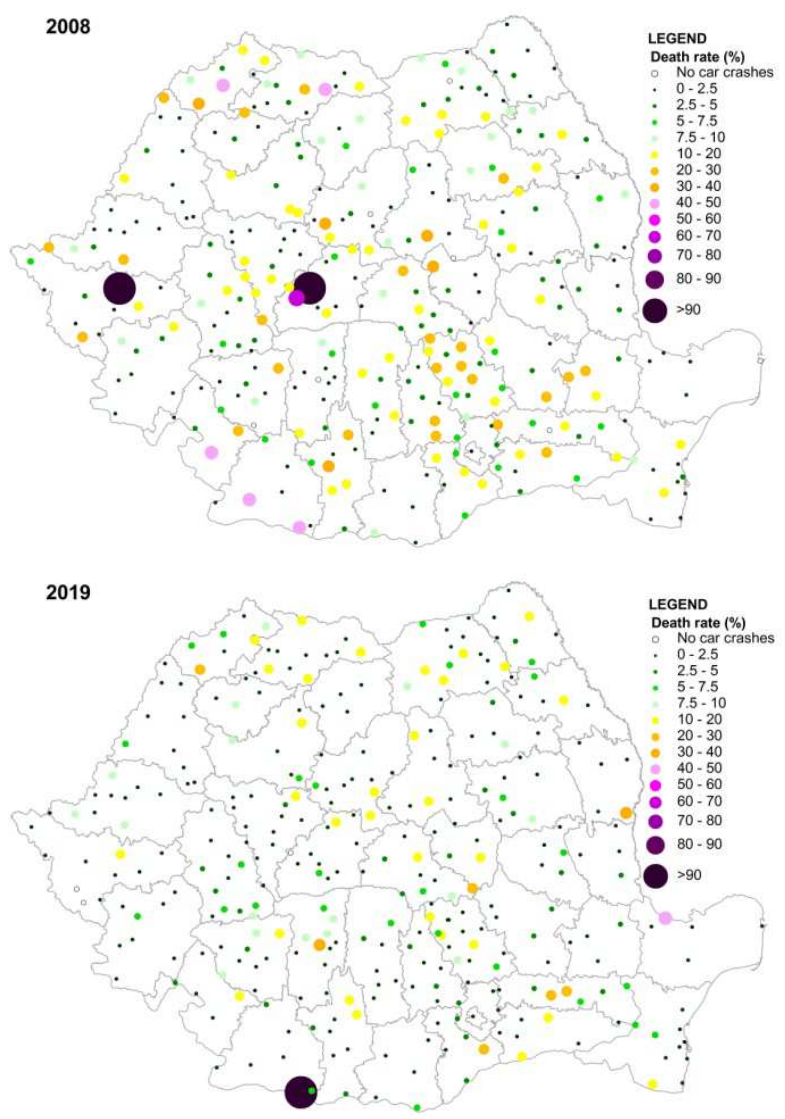

Fig. 10. Spatial distribution of cities per classes of death rate values in 2008 and 2019.

These results are consistent with those obtained relative to the fatality rate per 100,000 urban inhabitants, and relative to the average value of road traffic deaths at the national level for the entire reference period, which can be concluded as a general decrease in the severity of the road crashes in the Romanian cities and towns.

\subsection{Synthetic discussion}

This is a complex study at the national level, for an extended period that covers the period immediately after Romania's integration into the European Union and ending exactly at the beginning of the pandemic period. This period coincides with a massive migration abroad, increase in income, which is in direct relation with the increase in purchasing power 
and implicitly the number of private cars. The beginning of the period coincides with the first steps in developing road infrastructure in Romania. However, the rate of motorisation has exceeded the rate of road infrastructure development. In the same period, we note a clear development of metropolitan areas, their early signs being proved by the development of residential areas at the periphery of the large urban centres. Road infrastructure has not been a priority in the urban development in this period, thus, the model of road network remained the same as the one developed in the socialist and post-socialist period (before and after 1990), dominantly centripetal. This means that most of the cities in Romania have experienced the overlapping of three types of road traffic: local, metropolitan and transit, on an undersized network designed according to the values of traffic characteristic to the " 70 s. On the other hand, in the case of towns we note a slightly different context. Most of the small towns in Romania are part of an artificial urban development; they were declared urban areas, yet without benefiting from infrastructure adjustments and development. In their case two types of traffic is overlapped, transit and local, mostly without urban public transportation services. Although in some cases of large cities, the existence of ring roads and motorways contributed to the decrease of the transit traffic, the number of road crashes maintained high due to the development of the residential areas in the metropolitan area, the commuting for work and education of the population living in the periurban areas highly contributing to the traffic congestion in the city centre. The constant high values of urban road crashes incidence in the last 12 years is directly influenced by the continuously increasing motorisation level at the national level and implicitly in urban areas (Fig. 11).

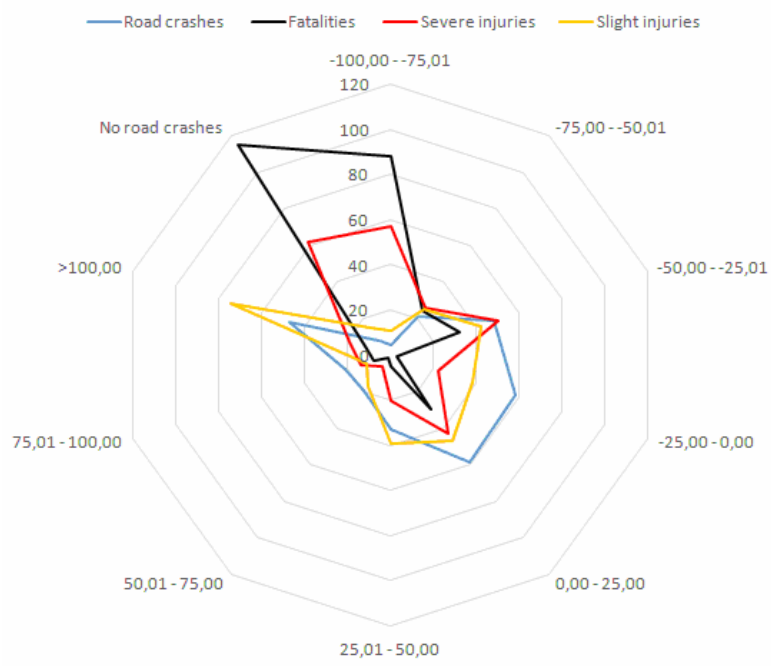

Fig. 11. Comparative trends in the relative growth (2008-2019) of road crashes and effects on people involved.

The increase in the number of slightly injured persons is the expression of the increase of motorisation and the preference of urban community for private transport against public transport due to its low attractiveness in large cities or even due to the lack of public transport in small towns. Thus, although with applied measures, the effects of agglomeration, traffic congestion with private vehicles cannot be so easily and visibly alleviated.

The decrease in the number of fatalities in almost half of the cities and towns in Romania shows the positive results of the implementation of some measures regarding transport and traffic safety. Alternatives of sustainable transport, green transport, public transport or even walking are still insufficiently developed or promoted as alternatives to the private transport or for the urban population to become aware of the advantages of their use.

The results of this study are relevant for policymakers to develop strategies and implement measures to decrease the number of urban road crashes and implicitly the fatality rate, increase urban mobility, improve and adjust road transport legislation, focusing on prevention and education to increase awareness of the drivers, to enhance efforts towards the construction of the major transport infrastructure, namely ring roads and highways, enhance efforts to develop sustainable urban transport (green transport) - bicycle lanes, public transportation, discourage the use of private cars for local purposes (education and work), extension/development of metropolitan public transport for the population that commutes daily to work and school from the periurban areas to the city, improve connection between the major points of interest within the city (i.e., airport, train station, residential areas, major malls that are located within the city or at the periphery) which are all vectors for traffic concentration in certain areas within the city.

\section{CONCLUSIONS}

We performed an analysis on the road safety in the urban areas in Romania based on the dynamics in the incidence and effects of road traffic crashes on the people involved (categorized into deceased, severely injured and slightly injured) over a 12-year reference period. The main aim was to identify the urban poles of risk, where the trends in the dynamics of road crashes incidence, and the effects on the people involved show increase or stagnation during the period from 2008 to 2019. We investigated this phenomenon at the local territorial administrative level, fact that provides a useful insight for authorities and policy makers to further identify the most appropriate measures, strategies and policies to design and manage sustainable urban development from the perspectives of urban mobility and safety. The indicators were analysed yearly, for the entire period, and comparatively relative to the start year and end year of the reference period. Cities and towns in Romania were grouped and 
classified based on their clustering either relative to the mean value (in the case of the number of road traffic crashes) or in relation to the variation for the entire period (in the case of fatalities, severely and slightly injured persons involved in urban road traffic crashes). We calculated the fatality rate per 100,000 urban inhabitants and as a share of people deceased from the total number of persons involved to thoroughly reflect the most severe impact of road traffic crashes on the participants in traffic and on the urban community. Results were presented by making distinction between cities and towns in Romania by their rank in the national hierarchy. Although results for every indicator occasionally showed several random extreme values due to the arbitrary nature of road traffic crashes, we were able to distinguish the cities and towns that are most affected by this negative phenomenon; of them, all 11 rank 1 cities, identified as socioeconomic poles of development are most prone to the occurrence road traffic crashes and record the highest values of impact. Specific initiatives for planning and development for sustainable urban transport plans are needed to tackle road traffic difficulties regarding safety and security, decrease the vulnerability of road users and enhance mobility within the functional city and outside in relation to periurban and suburban areas.

\section{REFERENCES}

Abdi T. A., Hailu B. H., Adal T. A., van Gelder P. H. A. J. M., Hagenzieker M. P., Carbon C. C. (2017), Road crashes in Addis Ababa, Ethiopia: Empirical findings between the years 2010 and 2014 . African Research Review: An International Multidisciplinary Journal, 11(2), 1-13. DOI: http://dx.doi.org/10.4314/afrrev.v11i2.1

Abdulhafedh A. (2017), Identifying vehicular crash high risk locations along highways via spatial autocorrelation indices and Kernel Density Estimation. World Journal of Engineering and Technology, 5, 198215. DOI: 10.4236/wjet.2017.52016

Aguero-Valverde J., Jovanis P. P. (2006), Spatial analysis of fatal and injury crashes in Pennsylvania. Accident Analysis and Prevention, 38, 618-625. DOI: https://doi.org/10.1016/j.aap.2005.12.006

Anderson T. (2007), Comparison of spatial methods for measuring road accident "hot spots": A case study of London. Journal of Maps, 3(1), 55-63. DOI: https://doi.org/10.1080/jom.2007.9710827

ASRO (2020), Sustainable cities and communities indicators for city services and quality of life. ISO 37120:2018. Organismul Național de Standardizare. URL: https://www.asro.ro/dezvoltarea-sustenabila-acomunitatilor-urbane-cu-ajutorul-standardului-sr-iso37120/

Bellos V., Ziakopoulos A., Yannis G. (2020), Investigation of the effects of tourism on road crashes.
Journal of Transportation Safety \& Security, 12(6), 782799. DOI:

httos://doi.org/10.1080/19439962.2018.1545715

Benedek J., Ciobanu S. M., Man T. C. (2016), Hotspots and social background of urban traffic crashes: A case study of Cluj-Napoca (Romania). Accident Analysis and Prevention, 87, 117-126. DOI: 10.1016/j.aap.2015.11.026

Bíl M., Andrášik R., Sedoník J. (2019), A detailed spatiotemporal analysis of traffic crash hotspots. Applied Geography, 107, 82-90. DOI: https://doi.org/10.1016/j.apgeog.2019.04.008

Cadar R. D., Boitor M. R., Dumitrescu M. (2017), Effects of Traffic Volumes on Accidents: The Case of Romania's National Roads. Geographia Technica, 12(2), 20-29. DOI: 10.21163/GT_2017.122.03

Călinoiu G., Mincă D. G., Furtunescu F.L. (2012). Analysis of Traffic Accidents in Romania, 2009. Romanian Journal of Internal Medicine, 5O(1), 93-101.

Chen X., Huang L., Dai D., Zhu M., Jin K. (2018), Hotspots of road traffic crashes in a redeveloping area of Shanghai. International Journal of Injury Control and Safety Promotion, 25(3), 293-302. DOI: 10.1080/17457300.2018.1431938

Cheng Z., Zu Z., Lu J. (2019), Traffic crash evolution characteristic analysis and spatiotemporal hotspot identification of urban road intersections. Sustainability, 11, 160 . DOI: https://doi.org/10.3390/su1101016o

Coşciug A., Ciobanu S. M., Benedek J. (2017), The safety of transnational imported second-hand cars: A case study on vehicle-to-vehicle crashes in Romania. Sustainability, $\quad 9, \quad 2380$. https://doi.org/10.3390/su9122380

Dandona R., Mishra A. (2004), Death due to road traffic crashes in Hyderabad city in India: Need for strengthening surveillance. The Medical Journal of India, 17(2), 67-72. PMID: 15141599

De Silva V., Tharindra H., Vissoci J. R. N., Andrade L., Mallawaarachichi B. C., Østbye T., Staton C. A. (2018), Road traffic crashes and built environment analysis of crash hotspots based on local police data in Galle, Sri Lanka. International Journal of Injury Control and Safety Promotion, 25(3), 311-318. DOI: 10.1080/17457300.2018.1431932

Dezman Z., De Andrade L., Vissoci J. R., ElGabri D., Johnson A., Hirshon J. M. (2016), Hotspots and causes of motor vehicle crashes in Baltimore, Maryland: A geospatial analysis of five years of police crash and census data. Injury, 47, 2450-2458. DOI: 10.1016/j.injury.2016.09.002

Drosu A., Cofaru C., Popescu M. V. (2020), Influence of Weather Conditions on Fatal Road Accidents on Highways and Urban and Rural Roads in Romania. International Journal of Automotive Technology, 21(2), 309-317. DOI 10.1007/s12239-020o029-4 
Eckley D. C., Curtin K. M. (2013), Evaluating the spatiotemporal clustering of traffic incidents. Computers, Environment \& Urban Systems, 37, 70-81. DOI: $10.1016 /$ j.compenvurbsys.2012.06.004

El-Sadig M., Nelson Norman J., Lloyd O. L., Romilly P., Bener A. (2002), Road traffic accidents in the United Arab Emirates: Trends of morbidity and mortality during 1977-1998. Accident Analysis and Prevention, 34(4), 465-476. DOI: 10.1016/sooo14575(01)0oo44-6

Elvik R. (2008), A survey of operational definitions of hazardous road locations in some European countries. Accident Analysis and Prevention, 40, 1830-1835. DOI: 10.1016/j.aap.2008.08.001

Erdogan S. (2009), Explorative spatial analysis of traffic accident statistics and road mortality among the provinces of Turkey. Journal of Safety Research, 40(5), 341-351. DOI:

https://doi.org/10.1016/j.jsr.2009.07.006

Erdogan S., Yilmaz I., Baybura T., Gullu M. (2008), Geographical Information Systems aided traffic accident analysis system case study: City of Afyonkarahisar. Accident Analysis and Prevention, 40, 174-181. DOI: 10.1016/j.aap.2007.05.004

European Commission (2010), Road Safety Programme 2011-2020: detailed measures. Memo/10/343. Brussels. URL:

https://ec.europa.eu/commission/presscorner/detail/e n/MEMO_10_343

European Commission (2013), COM 2013 (913). Communication from the Commission to the European Parliament, the Council, the European Economic and Social Committee and the Committee of the Regions. Together towards competitive and resource-efficient urban mobility. URL: https://eur-lex.europa.eu/legalcontent/EN/TXT/HTML/?uri=CELEX:52013DCo913\& from=EN. Accessed on November 30, 2021.

European Commission (2021), European Urban Mobility Framework. Questions and Answers. Press article. Strasbourg, 14 December 2021. URL: https://ec.europa.eu/commission/presscorner/detail/e n/qanda_21_6729

European Parliament (2021), Road fatality statistics in the EU. URL:

https://www.europarl.europa.eu/news/en/headlines/s ociety/20190410STO36615/road-fatality-statistics-inthe-eu-infographic

European Transport Safety Council (2018), Briefing: 5th EU Road Safety Action Programme 20202030. URL:

https://ec.europa.eu/commission/presscorner/detail/e n/MEMO_10_343

Ghandour A. J., Hammoud H., Al-Hajj S. (2020), Analyzing factors associated with fatal road crashes: A machine learning approach. International Journal of Environmental Research and Public Health, 17, 4111. DOI: https://doi.org/10.339o/ijerph17114111
Ipingbemi O. (2008), Spatial analysis and socioeconomic burden of road crashes in south-western Nigeria. International Journal of Injury Control and Safety Promotion, 15(2), 99-108. DOI: https://doi.org/10.1080/17457300802150785

Ivan K., Haidu I. (2012), The spatio-temporal distribution of road accidents in Cluj-Napoca. Geographia Technica, 2, 32-38.

Ivan K., Benedek J., Ciobanu S. M. (2019), Schoolaged pedestrian-vehicle crash vulnerability. Sustainability, 11, 1214. DOI: https://doi.org/10.3390/su11041214

Ivan K., Haidu I., Benedek J. (2015), Identification of traffic accident risk prone areas under low-light conditions. Natural Hazards and Earth System Sciences, 15, 2059-2068. DOI:

https://doi.org/10.5194/nhess-15-2059-2015

Jones S., Odero K., Adanu E. K. (2020), Road crashes in Namibia: Challenges and opportunities for sustainable development. Development Southern Africa, 37(2), 295-311. DOI:

https://doi.org/10.1080/0376835X.2019.1659131

Kingham S., Sabel C. E., Bartie P. (2011), The impact of the "school run" on road traffic accidents: A spatial-temporal analysis. Journal of Transport Geography, 19, 705-711. DOI:

https://doi.org/10.1016/j.jtrangeo.2010.08.011

Liu C., Sharma A. (2018), Using the multivariate spatio-temporal Bayesian model to analyze traffic crashes by severity. Analytic Methods in Accident Research, 17, 14-31. DOI:

https://doi.org/10.1016/j.amar.2018.02.001

Liu C., Sharma A. (2017), Exploring spatio-temporal effects in traffic crash trend analysis. Analytic Methods in Accident Research, 16, 104-116. DOI: 10.1016/j.amar.2017.09.002

Lobo A., Ferreira S., Iglesias I., Couto A. (2019), Urban road crashes and weather conditions: Untangling the effects. Sustainability, 11, 3176. DOI: https://doi.org/10.3390/su11113176

Ma X., Chen S., Chen F. (2017), Multivariate spacetime modelling of crash frequencies by injury severity levels. Analytic Methods in Accident Research, 15, 2940. DOI: 10.1016/J.AMAR.2017.06.001

Mincă D. G., Furtunescu F. L., Călinoiu G., Domnariu C. D., Costea R. V. (2013), Profile of Persons Involved in Traffic Accidents in Romania. Romanian Journal of Legal Medicine, 21(2) 155-160. DOI: 10.4323/rjlm.2013.155

Omer I., Gitelman V., Rafe் Y., Lerman Y., Kaplan N., Doveh E. (2017), Evaluating crash risk in urban areas based on vehicle and pedestrian modelling. Geographical Analysis, 49(4), 387-408. DOI: https://doi.org/10.1111/gean/12128

Ouni F., Belloumi M. (2019), Pattern of road traffic crash hot zones versus probable hot zones in Tunisia: A geospatial analysis. Accident Analysis and Prevention, 128, 185-196. DOI: 10.1016/j.aap.2019.04.008 
Patel A., Krebs E., Andrade L., Rulisa S., Vissoci J. R. N., Staton C. A. (2016), The epidemiology of road traffic injury hotspots in Kigali, Rwanda from police data. BMC Public Health, 16, 697. DOI: 10.1186/s12889-016-3359-4

Plug C., Xia J., Caulfield C. (2011), Spatial and temporal visualization techniques for crash analysis. Accident Analysis and Prevention, 43, 1937-1946. DOI: 10.1016/j.aap.2011.05.007

Rodríguez-Morales B., Díaz-Varela E. R., Marey-Pérez M. F. (2013), Spatio-temporal analysis of vehicle collision involving wild boar and roe deer in NW Spain. Accident Analysis and Prevention, 60, 121133. DOI: 10.1016/j.aap.2013.07.032

Romanian Parliament (2001), Law no. 351/2001 on the approval of the National Spatial Planning Plan Section IV - The network of localities, published in Monitorul Oficial al României, no. 408 of 24 July 2001, with subsequent modifications. URL: http://www.cdep.ro/pls/legis/legis_pck.htp_act_text?i $\mathrm{dt}=28862$

Soltani A., Askari S. (2017), Exploring spatial autocorrelation of traffic crashes based on severity. Injury, 48, 637-647. DOI: 10.1016/j.injury.2017.01.032 Steenberghen A., Aerts K., Thomas L. (2010), Spatial clustering of events on a network. Journal of Transportation Geography, 18, 411-418. DOI: 10.1016/j.jtrangeo.2009.08.005

Sumaila A. F. (2013), Road crashes trends and safety management in Nigeria. Journal of Geography and Regional Planning, 6(3), 53-62. DOI: 10.5897/JGRP2013.0318

Târnu L., Deac C. (2018a). Considerations on the Right of Way as Cause of Road Accidents in Romania. MATEC Web of Conferences 184, Annual Session of
Scientific Papers IMT ORADEA. DOI: https://doi.org/10.1051/matecconf/201818401012

Târnu L., Deac C. (2018b), Analysis of the Evolution of the Number of Fatal Road Accidents in Romania. MATEC Web of Conferences 184, Annual Session of Scientific Papers IMT ORADEA. DOI: https://doi.org/10.1051/matecconf/201818401011

Toran Pour A., Moridpour S., Rajabifard A., Tay R. (2016), Spatial and temporal distribution of pedestrian crashes in Melbourne Metropolitan Area. Australasian Transport Research Forum, 2016 Proceedings, 16-18 November, Melbourne, Australia. DOI: $10.1080 / 15389588.2017 .1341630$

Truong L. T., Kien L. M., Vu T. A. (2016), Spatiotemporal and random parameter panel data models of traffic crash fatalities in Vietnam. Accident Analysis and Prevention, 94, 153-161.

Wang Y., Kockelman K. M. (2013), A Poissonlognormal conditional autoregressive model for multivariate spatial analysis of pedestrian crash counts across neighborhoods. Accident Analysis and Prevention, 60, 71-84. DOI: 10.1016/j.aap.2013.07.030 WHO (2018), Global Status Report in Road Safety. Geneva, Switzerland: World Health Organization.

Zahran E. M. M., Tan S. J., Yap Y. H., Rahman E. K. A., Husaini N. H. (2017), A novel approach for identification and ranking of road traffic accident hotspots. MATEC Web of Conferences, 124, 04003. DOI:

https://doi.org/10.1051/matecconf/201712404003

Zotic V., Alexandru D.-E., Egresi I. O. (2020), General Features of Road Crashes in Cluj County, Romania. Spatiality and Causality. Territorial Identity and Development, 5(1), 99-123. DOI: http://doi.org/10.23740/TID120205 